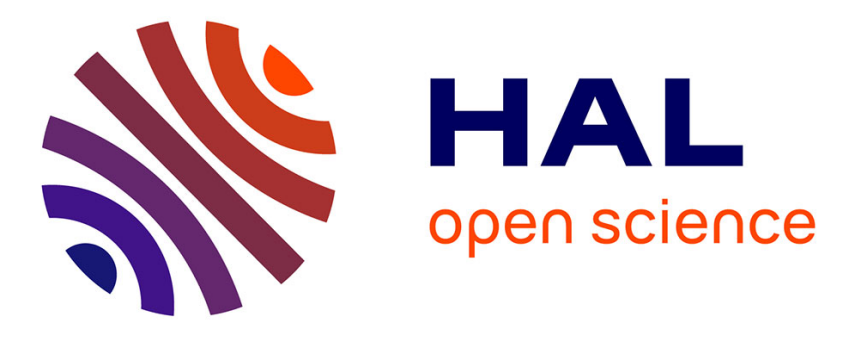

\title{
Canopy structure analysis for estimating forest regeneration dynamics and growth in Nothofagus pumilio forests
}

Guillermo Martínez Pastur, Pablo Peri, Juan Cellini, María Lencinas, Barrera, Ivancich

\section{To cite this version:}

Guillermo Martínez Pastur, Pablo Peri, Juan Cellini, María Lencinas, Barrera, et al.. Canopy structure analysis for estimating forest regeneration dynamics and growth in Nothofagus pumilio forests. Annals of Forest Science, 2011, 68 (3), pp.587-594. 10.1007/s13595-011-0059-1 . hal-00930793

\section{HAL Id: hal-00930793 https://hal.science/hal-00930793}

Submitted on 1 Jan 2011

HAL is a multi-disciplinary open access archive for the deposit and dissemination of scientific research documents, whether they are published or not. The documents may come from teaching and research institutions in France or abroad, or from public or private research centers.
L'archive ouverte pluridisciplinaire HAL, est destinée au dépôt et à la diffusion de documents scientifiques de niveau recherche, publiés ou non, émanant des établissements d'enseignement et de recherche français ou étrangers, des laboratoires publics ou privés. 


\title{
Canopy structure analysis for estimating forest regeneration dynamics and growth in Nothofagus pumilio forests
}

\author{
Guillermo J. Martínez Pastur • Pablo L. Peri • \\ Juan M. Cellini • María V. Lencinas • Marcelo Barrera • \\ Horacio Ivancich
}

Received: 26 April 2010 /Accepted: 20 August 2010/Published online: 8 April 2011

(C) INRA and Springer Science+Business Media B.V. 2011

\begin{abstract}
- Introduction Silviculture systems applied in Nothofagus pumilio forests are based on opening the canopy to stimulate natural regeneration by modifying light and soil moisture. The objective is to evaluate regeneration dynamics of $N$. pumilio along different forest canopy and solar radiation gradients.

- Materials and methods Regeneration data and seed production were obtained in 98 permanent plots established in old-growth and harvested stands along a crown cover gradient (19-93\%). Volumetric soil water content and basal area were also measured, while crown cover and solar radiation transmission were estimated using hemispherical photographs. Sapling height was modeled using plant age, crown cover, and solar radiation transmission of the stands as explanatory variables.
\end{abstract}

- Results Natural regeneration dynamics were closely related to crown cover values, which determined seed

Handling Editor: Douglas Jacobs

G. J. Martínez Pastur $(\bowtie) \cdot M$. V. Lencinas $\cdot$ H. Ivancich

Centro Austral de Investigaciones Científicas (CONICET),

Houssay 200 (9410) Ushuaia,

Tierra del Fuego, Argentina

e-mail: gpastur@conicet.gov.ar

P. L. Peri

Universidad Nacional de la Patagonia Austral-CONICET-Instituto

Nacional de Tecnología Agropecuaria,

cc 332 (9400) Río Gallegos,

Santa Cruz, Argentina

J. M. Cellini $\cdot$ M. Barrera

Laboratorio de Investigaciones de Sistemas Ecológicos y

Ambientales (LISEA-UNLP),

Diagonal 113 no. 469 (1900) La Plata,

Buenos Aires, Argentina production and the successful establishment and subsequent regeneration growth. Height growth was found to be related to crown cover and solar radiation transmission, where $N$. pumilio regeneration is optimized at intermediate crown cover levels ( $45 \%$ crown cover, 0.5 effective leaf area index, $26 \mathrm{~W} \mathrm{~m}^{2}$ global radiation, and $65 \%$ percentage of global radiation).

- Conclusion These findings can be used to develop new silvicultural methods or to adjust the current practices to ensure regeneration establishment and maximize height growth at the stand level.

Keywords Silviculture $\cdot$ Regeneration dynamics $\cdot$ Light availability $\cdot$ Soil moisture $\cdot$ Hemispherical photographs

\section{Introduction}

The temperate forests of southern Chile and Argentina are one of the world's most pristine wilderness areas (Mittermeier et al. 2002). A forest management strategy that takes account of the natural processes and dynamics of the dominant species in forests is important for conservation. In natural forests, seedlings and saplings of Nothofagus species often survive and grow slowly for long periods of time in the understory (Rebertus and Veblen 1993; Cuevas 2002) and are able to respond quickly after the opening of gaps due to windstorms, ice damage, timber harvesting, or beaver engineering (Rebertus et al. 1997; Heinemann et al. 2000; Martínez Pastur et al. 2000, 2009; Anderson et al. 2009). Following harvesting disturbance, new seedling regeneration is typically vigorous and abundant and has been shown to rapidly outgrow the preexisting regeneration (Gea et al. 2004). 
Several silvicultural systems have been applied in $N$. pumilio (Poepp. and Endl.) Krasser forests ranging from light selective harvests to clear-cuts (Gea et al. 2004). The most commonly applied methods over the last decade were shelterwood and variable retention cuts (Martínez Pastur et al. 2000, 2009). The silvicultural prescriptions applied under these systems are based on canopy opening to stimulate natural regeneration by modifying soil moisture and light availability at ground level (Heinemann et al. 2000; Lencinas et al. 2007; Martínez Pastur et al. 2007a). To improve these silvicultural practices, it is necessary to understand the basis of inter-specific differences in seedling and sapling growth (Messier et al. 1999), as well as the impact over flowering and seeding processes (Martínez Pastur et al. 2008). The success or failure of different silvicultural systems depends on the functional responses of the species to different environmental conditions, particularly the extent of canopy opening. Therefore, a balance between silvicultural systems that favor timber yield and functional integrity of the forest ecosystem is needed.

In Nothofagus forests, regeneration growth conditions are improved when the canopy is gradually opened. However, while greater canopy opening reduces the effective sheltering function of the remnant overstory (Howard 1973; Nuñez and Bowman 1986), soil moisture and radiation at ground level increase, which have positive or negative influence effects over regeneration. Both factors affect the regeneration growth rate by changing their ecophysiological performance (Lencinas et al. 2007; Martínez Pastur et al. 2007a; Peri et al. 2009). Therefore, in this study, the objectives are: (1) to evaluate the regeneration dynamics of $N$. pumilio along different forest canopy structures and solar radiation transmissions and (2) based on these results discuss the current silvicultural practices. The tested hypotheses are: (1) change in canopy structure by modifying rainfall and solar radiation interception changed the availability of these resources influencing regeneration establishment and growth and (2) regeneration growth can be predicted using canopy structure related variables and age.

\section{Methods}

2.1 Study sites, forest structure, and silvicultural practices

Data were obtained from three study sites located in pure $N$. pumilio stands at San Justo Ranch $\left(54^{\circ} 06^{\prime} \mathrm{S}, 68^{\circ} 37^{\prime} \mathrm{W}\right)$ harvested to a shelterwood prescription in 1997 (4 ha) and to shelterwood and variable retention prescriptions in 2001 (50 ha), and Los Cerros Ranch $\left(54^{\circ} 18^{\prime} \mathrm{S}, 67^{\circ} 49^{\prime} \mathrm{W}\right.$ ) harvested to a variable retention prescription in 2004 (70 ha) in Tierra del Fuego, Argentina. Undisturbed old growth forests located close to the harvested areas (5-10 ha each) were also selected for regeneration sampling. In all of the studied forests, there are a full range of site qualities (SQ) defined according to site index curves at base age 60 years ( $\mathrm{SI}_{60}$; for details, see Martínez Pastur et al. 1997, 2009): $\mathrm{SQI}=\mathrm{SI}_{60}>19.8 \mathrm{~m}, \mathrm{SQII}=\mathrm{SI}_{60} 16.5-19.8 \mathrm{~m} ; \mathrm{SQIII}=\mathrm{SI}_{60}$ $13.1-16.5 \mathrm{~m}$; $\mathrm{SQIV}=\mathrm{SI}_{60} 9.8-13.1 \mathrm{~m}$, and $\mathrm{SQV}=\mathrm{SI}_{60}<$ $9.8 \mathrm{~m}$. Stands harvested to shelterwood or variable retention prescriptions (Martínez Pastur et al. 2000, 2007b, 2009) generated different canopy openness and microenvironment conditions. In the shelterwood harvests, $30 \mathrm{~m}^{2} \mathrm{ha}^{-1}$ basal area of dominant trees were left evenly distributed throughout the harvested area. In the variable retention harvests, one circular aggregate of $30 \mathrm{~m}$ radius was retained per hectare, and evenly dispersed dominant trees were retained at $10-15 \mathrm{~m}^{2} \mathrm{ha}^{-1}$ basal area between the aggregates.

\subsection{Regeneration sampling}

Data were recorded from 2002 to 2009 in 98 permanent regeneration plots (26 in San Justo Ranch of 1 to $2 \mathrm{~m}^{2}$ each and 72 in Los Cerros Ranch of $1 \mathrm{~m}^{2}$ each) in harvested stands ( $n=14$ in shelterwoods, $n=22$ inside the aggregates, $n=40$ in the dispersed retention) and old-growth forests ( $n=$ 22) along a crown cover (CC) gradient (19-93\%). The plots were randomly located in old growth forests and shelterwoods, while in the variable retention areas, the plots were located along transects laid out from the center of the aggregates to a point within the dispersed retention areas most distant from the aggregates, from the area of highest crown cover to the point of lowest crown cover. Seedling (1-year-old plants) and sapling (2-10-year-old plants) density, height, and age were measured in each plot. Age was determined in the field from annual growth scars in the stems (Cuevas 2002; Gea et al. 2004), while height was measured from the base to the top of the longest extended shoot. Circular $0.25 \mathrm{~m}^{2}$ seed traps were located close to each regeneration plot, and seeds were collected each year after leaf fall during May. The percentage of seeds that fall during the winter season is scarce (ca. 5\% according to Martínez Pastur et al. 2008) and was not included in the analysis. Establishment was measured as the number of seedlings, while mortality was determined as the number of dead or missed plants up to 2-year-old saplings in the plots. Regeneration plots that were severely disturbed after the harvesting (e.g., by windthrow) were not included in the analyses.

\subsection{Canopy structure and related variables}

In the center of each regeneration plot, hemispherical photographs of forest canopy were taken at $1 \mathrm{~m}$ above the 
ground level with an 8-mm fish-eye lens (Sigma, Japan) mounted on a $35-\mathrm{mm}$ digital camera (Nikon, Japan) with a tripod leveling head. Each photograph was orientated with the upper edge towards the magnetic north. Photographs were taken when there was no direct sunshine (Roxburgh and Kelly 1995). Gap Light Analyzer software v.2.0 (Frazer et al. 2001) was used to define: CC; effective leaf area index (LAI) defined as the effective amount of leaf surface area per unit ground area integrated over the zenith angles $0^{\circ}-60^{\circ}$ (Stenburg et al. 1994); global radiation (GR) at understory level as the amount of direct and diffuse radiation transmitted through the canopy along the growing season (November to March), and percentage of global radiation (PGR) as the ratio of GR and the amount of direct and diffuse radiation incident on a horizontal surface located above forest canopy. The following parameters were used: (a) specific projection of the lens; (b) sky-region grid of $20 \times 4$; (c) constant value of $1367 \mathrm{~W} \mathrm{~m}^{2}$ for total radiant flux of the sun (Hardya et al. 2004) and 0.6 clear-sky transmission coefficient; and (d) radiation data provided by Universidad de Magallanes (Santana 2006; Santana et al. 2006) and VAG-Ushuaia (Global Atmospheric Watch Station). Finally, basal area $\left(\mathrm{BA} ; \mathrm{m}^{2} \mathrm{ha}^{-1}\right.$ ) and volumetric soil water content (VSW; \%) in the first $10 \mathrm{~cm}$ forest soil using a MP406 moisture probe (ICT, Australia) were also measured in each regeneration plot.

\subsection{Statistical analysis and regeneration height model prediction}

We used two-way ANOVA to analyze whether the response variable of seedling density ( $\mathrm{S}$; thousand $\mathrm{ha}^{-1}$ ), number of saplings ( $\mathrm{S}>1$; thousand $\mathrm{ha}^{-1}$ ), seedling establishment (EST; thousand $\mathrm{ha}^{-1}$ ), mortality (MOR; thousand $\mathrm{ha}^{-1}$ year ${ }^{-1}$ ) and seed production (SP; million $\mathrm{ha}^{-1}$ year $^{-1}$ ) differed between CC $(<40 \%, 40-60 \%, 60-80 \%,>80 \%)$ and years after harvesting (1-2, 3-4, 5-6, >7 years). Complementary oneway ANOVA was done using the same $\mathrm{CC}$ levels to analyze LAI, GR, PGR, BA, and VSW. A post hoc Tukey's test was used for all mean comparisons $(p<0.05)$.

A model to predict average sapling height was fitted, according to their age along CC, LAI, GR, and PGR gradients. Data of 14,024 sapling measurements (height and age) were obtained from the regeneration plots. Only regeneration established after the harvesting was used for the analysis. Equation 1 was fitted by nonlinear regression technique. Adjusted $r^{2}\left(r^{2}\right.$-adj.), standard error of estimation (SEE), and mean absolute error (MAE) were used to evaluate model fitness. The model was assumed to be:

$H=a A^{b}\left(c+d X+e X^{2}\right)$ where $H=$ average sapling height (centimeters), $A=$ sapling age (years), $X$ is CC (\%), LAI, GR $\left(\mathrm{W} \mathrm{m}^{2}\right)$ or PGR (\%), and $a-e=$ adjusted parameters.

Statistical analyses were carried out by using the Statgraphics Plus 5.1 package (Statistical Graphics Corp, 1994-2000).

\section{Results}

\subsection{Silvicultural treatments characterization}

Old-growth forests had a CC of $88.5 \pm 1.9 \%$ (average \pm standard deviation), LAI of $2.5 \pm 0.2$, GR of $6.1 \pm 0.9 \mathrm{~W} \mathrm{~m}^{2}$, PGR of $15.3 \pm 2.3 \%$, BA of $90.7 \pm 17.3 \mathrm{~m}^{2} \mathrm{ha}^{-1}$, and VSW of $19.7 \pm 8.1 \%$. The variable retention treatment presented a gradient from the unmanaged sectors inside the aggregates to the furthest distances between aggregates. Inside the aggregates radiation values were slightly higher (GR of 7.6 \pm $1.7 \mathrm{~W} \mathrm{~m}^{2}$ and PGR of $19.2 \pm 4.4 \%$ ) while the other variables were slightly lower (CC of $80.4 \pm 3.6 \%$, LAI of $2.3 \pm 0.4$, BA of $71.1 \pm 20.9 \mathrm{~m}^{2} \mathrm{ha}^{-1}$, and VSW of $19.4 \pm 7.3 \%$ ) compared to old growth forests due to the edge effect. The studied variables drastically changed in the dispersed retention, with lower changes in plots under the influence of the aggregates (within $20 \mathrm{~m}$ of the aggregate edge) than in the plots furthest away from any aggregate (20-40 $\mathrm{m}$ to the aggregate edge). The areas under the influence of the aggregates presented a $\mathrm{CC}$ of $51.1 \pm 10.0 \%$, LAI of $0.7 \pm 0.3$, GR of $23.5 \pm 5.3 \mathrm{~W} \mathrm{~m}^{2}$, PGR of $59.3 \pm 13.3 \%$, BA of $21.7 \pm 17.2 \mathrm{~m}^{2} \mathrm{ha}^{-1}$, and VSW of $31.3 \pm 17.5 \%$, while the plots in the dispersed retention and furthest from the aggregates had a CC of $42.5 \pm 10.4 \%$, LAI of $0.4 \pm 0.2$, GR of $28.4 \pm 4.5 \mathrm{~W} \mathrm{~m}^{2}$, PGR of $71.7 \pm$ $11.4 \%$, BA of $7.8 \pm 5.6 \mathrm{~m}^{2} \mathrm{ha}^{-1}$, and VSW of $33.2 \pm 11.7 \%$. The dispersed retention areas showed slightly lower values compared with the shelterwood.

\subsection{Regeneration dynamics, canopy structure, and solar} radiation transmission

There were significant differences for S, EST, MOR, and SP with respect to crown cover (Table 1). These variables all increased as $\mathrm{CC}$ increased, ranging from 180,000 to $623,000 \mathrm{ha}^{-1}$ for S, 20,000-429,000 ha ${ }^{-1}$ for EST, 18,000-319,000 ha ${ }^{-1}$ for MOR, and 0.6-9.0 million $\mathrm{ha}^{-1}$ year ${ }^{-1}$ for SP. The greatest difference in these variables was observed as CC increased from $40-60 \%$ to $60-80 \%$. Establishment was related to SP and MOR to previous EST year. Saplings presented the highest values at $60-80 \% \mathrm{CC}$ and lowest at $40-60 \% \mathrm{CC}$ but did not show significant differences $(p=0.142)$. When YAH was considered as main factor, significant differences were found for S, EST, and SP. Once again, saplings did not show a 
Table 1 ANOVA and means for CC (\%) and YAH analyzing S (thousand ha ${ }^{-1}$ ), S $>1$ (thousand ha ${ }^{-1}$ ), EST (thousand ha ${ }^{-1}$ ), MOR (thousand $\mathrm{ha}^{-1}$ year $^{-1}$ ), and SP (million $\mathrm{ha}^{-1}$ year $^{-1}$ ) in Nothofagus pumilio forests

\begin{tabular}{|c|c|c|c|c|c|c|}
\hline Factor & & $\mathrm{S}$ & $\mathrm{S}>1$ & EST & MOR & SP \\
\hline \multirow[t]{5}{*}{$\mathrm{CC}$} & $<40 \%$ & $180.2 \mathrm{a}$ & 160.3 & 19.9 a & $17.9 \mathrm{a}$ & $0.59 \mathrm{a}$ \\
\hline & $40-60 \%$ & $197.8 \mathrm{a}$ & 137.8 & $60.0 \mathrm{a}$ & $40.8 \mathrm{a}$ & $5.34 \mathrm{~b}$ \\
\hline & $60-80 \%$ & $553.7 \mathrm{~b}$ & 276.5 & $277.2 \mathrm{~b}$ & $185.9 \mathrm{ab}$ & $8.32 \mathrm{bc}$ \\
\hline & $>80 \%$ & $623.1 \mathrm{~b}$ & 194.1 & $428.9 \mathrm{~b}$ & $318.8 \mathrm{~b}$ & $9.03 \mathrm{c}$ \\
\hline & $\mathrm{F}(\mathrm{p})$ & $12.15(<0.001)$ & $1.83(0.142)$ & $12.45(<0.001)$ & $7.30(<0.001)$ & $11.62(<0.001)$ \\
\hline \multirow[t]{5}{*}{ YAH } & $1-2$ & $282.6 \mathrm{a}$ & 91.7 & $190.9 \mathrm{ab}$ & 0.2 & $3.78 \mathrm{a}$ \\
\hline & $3-4$ & $374.9 \mathrm{a}$ & 226.4 & $148.5 \mathrm{a}$ & 121.3 & $4.14 \mathrm{a}$ \\
\hline & $5-6$ & $263.6 \mathrm{a}$ & 182.4 & $81.2 \mathrm{a}$ & 192.5 & $4.21 \mathrm{a}$ \\
\hline & $>7$ & $633.7 \mathrm{~b}$ & 268.3 & $365.4 \mathrm{~b}$ & 249.2 & $9.11 \mathrm{~b}$ \\
\hline & $\mathrm{F}(\mathrm{p})$ & $5.23(0.001)$ & $2.06(0.105)$ & $4.28(0.005)$ & $2.04(0.107)$ & $7.16(0.001)$ \\
\hline $\mathrm{CC} \times \mathrm{YAH}$ & $\mathrm{F}(\mathrm{p})$ & $1.92(0.047)$ & $0.51(0.866)$ & $2.19(0.021)$ & $1.14(0.336)$ & $3.29(0.004)$ \\
\hline
\end{tabular}

Letters indicate differences using Tukey test $(p=0.05)$

$C C$ crown cover, $Y A H$ years after harvesting, $S$ number of seedlings, $S>1$ number of saplings, EST seedling establishment, $M O R$ seedling mortality, $S P$ seed production, $F$ Fisher test and probability between parentheses

significant difference $(p=0.105)$. The observed differences were associated with past mast seed years (e.g., the $\mathrm{S}$ observed in the $>7 \mathrm{YAH}$; Table 1) as well as the interactions found in these analysis.

There were significant differences for LAI, GR, PGR, $\mathrm{BA}$, and VSW with respect to changing crown cover (Table 2). These variables proportionally increased or decreased in their values as CC increased, except for VSW, which decreased from $25 \%$ to $31 \%$ at $<60 \%$ CC to $18-19 \%$ at $>60 \%$ CC levels.

\subsection{Sapling height model prediction}

The parameters and statistics of the models used to predict $\mathrm{H}$ with sapling age along CC, LAI, GR, and PGR gradients were presented in Table 3. The proposed model provided polymorphic curves, where sapling height increased up to a maximum value and then decreased for all studied ages (Fig. 1). The shapes of the curves were similar because the independent variables studied were highly correlated: CC$\mathrm{LAI}=0.973(p<0.001), \mathrm{CC}-\mathrm{GR}$ and $\mathrm{PGR}=-0.969(p<$ $0.001)$, LAI-GR and PGR $=-0.958(p<0.001)$, and GRPGR $=1.000(p<0.001)$. Sapling height increased when: (1) $\mathrm{CC}$ decreased, reaching to a maximum at $45 \%$ (mean height of $29.7 \mathrm{~cm}$ at 10 years old) and then decreased at lower CC levels; (3) LAI decreased, reaching to a maximum at 0.5 (mean height of $27.3 \mathrm{~cm}$ at 10 years old) and then decreased at lower LAI levels; (3) GR decreased, reaching to a maximum at $26 \mathrm{~W} \mathrm{~m}^{2}$ (mean height of $30.9 \mathrm{~cm}$ at 10 years old) and then decreased at lower GR levels; and (4) PGR decreased, reaching to a maximum at $65 \%$ (mean height of $30.9 \mathrm{~cm}$ at 10 years old) and then decreased at lower PGR levels.

Residual analysis of SEE showed a different pattern for each studied variable (Fig. 2). No tendencies of under and over-estimations were detected across the studied gradients. Standard error of the mean was higher in the lower and maximum values of each studied variables.

Table 2 ANOVA and means for CC (\%) analyzing effective LAI, GR (W m²), PGR (\%) at understory level transmitted through the canopy, BA $\left(\mathrm{m}^{2} \mathrm{ha}^{-1}\right)$, and VSW (\%) in Nothofagus pumilio forests

\begin{tabular}{|c|c|c|c|c|c|c|}
\hline Factor & & LAI & GR & PGR & BA & VSW \\
\hline \multirow[t]{5}{*}{$\mathrm{CC}$} & $<40 \%$ & $0.15 \mathrm{a}$ & $32.67 \mathrm{~d}$ & $82.58 \mathrm{~d}$ & $3.5 \mathrm{a}$ & $24.86 \mathrm{ab}$ \\
\hline & $40-60 \%$ & $0.58 \mathrm{~b}$ & $24.26 \mathrm{c}$ & $61.30 \mathrm{c}$ & $17.3 \mathrm{a}$ & $31.41 \mathrm{~b}$ \\
\hline & $60-80 \%$ & $1.85 \mathrm{c}$ & $11.24 \mathrm{~b}$ & $28.41 \mathrm{~b}$ & $56.0 \mathrm{~b}$ & $17.83 \mathrm{a}$ \\
\hline & $>80 \%$ & $2.56 \mathrm{~d}$ & $6.16 \mathrm{a}$ & $15.57 \mathrm{a}$ & $82.0 \mathrm{c}$ & $19.23 \mathrm{a}$ \\
\hline & $\mathrm{F}(\mathrm{p})$ & $275.45(<0.001)$ & $361.08(<0.001)$ & $361.08(<0.001)$ & $76.33(<0.001)$ & $7.54(0.001)$ \\
\hline
\end{tabular}

Letters indicates differences using Tukey test $(p=0.05)$

$F$ Fisher test and probability between parentheses 
Table 3 Parameters and statistics of the non-linear models of average seedling height after harvesting according to seedling age (2-10 years; Eq. 1) and CC $(\%)$, effective LAI, GR $\left(\mathrm{W} \mathrm{m}^{2}\right)$, and PGR (\%) at understory level transmitted through the canopy in Nothofagus pumilio forests

$r^{2}$-adj. adjusted $r^{2}, S E E$ standard error of estimation, $M A E$ mean absolute error

\begin{tabular}{llllll}
\hline Variable & Parameters & Statistics & Variable & Parameters & Statistics \\
\hline CC (\%) & $a=3.391 \times 10^{-4}$ & $r^{2}$-adj. $=55.52$ & LAI & $a=0.352$ & $r^{2}$-adj. $=56.38$ \\
& $b=1.232$ & SEE=4.71 & & $b=1.161$ & SEE=4.67 \\
& $c=2637.28$ & MAE $=2.97$ & & $c=5.212$ & MAE=2.93 \\
& $d=114.902$ & & $d=0.564$ & \\
& $e=-1.317$ & & & $e=-0.574$ & \\
GR $\left(\mathrm{W} \mathrm{m}^{2}\right)$ & $a=4.864 \times 10^{-4}$ & $r^{2}$-adj. $=58.95$ & PGR $(\%)$ & $a=4.274 \times 10^{-4}$ & $r^{2}$-adj. $=58.95$ \\
& $b=1.207$ & SEE=4.52 & & $b=1.207$ & SEE=4.52 \\
& $c=250.356$ & $\mathrm{MAE}=2.90$ & & $c=284.774$ & MAE=2.91 \\
& $d=286.032$ & & & $d=12885.2$ & \\
& $e=-5.537$ & & & $e=-9870.93$ & \\
\hline
\end{tabular}

\section{Discussion}

Old-growth $N$. pumilio forests have high crown closure and retained a large percentage of the rainfall (13-25\% for interception and 15-50\% for evapo-transpiration) reducing soil moisture at ground level (Frangi and Richter 1994; Martínez Pastur et al. 2007a). The high crown cover also reduces light availability at ground level. Harvesting, by opening the canopy, increased radiation at ground level, e. g. it was $2.4-2.9 \times$ greater with $50 \%$ original basal area (Caldentey et al. 2009). Natural regeneration dynamics and subsequent growth determined by biomass compartmentalization (Lencinas et al. 2007) and photosynthetic efficiency depend on the interaction between radiation levels and soil moisture. There is a negative interaction that can influence the fine root dynamics thus affecting nutrient and water uptake (Martínez Pastur et al. 2007a), as was cited for $N$. solandri and $N$. menziesii (Sun et al. 1995). In this study, closed canopies affected the regeneration dynamics and growth performance of the 1-10-year-old regenerating seedlings and saplings, which were improved at lower crown covers $(45 \% \mathrm{CC}$ and $0.5 \mathrm{LAI}$ ), higher radiation $\left(26 \mathrm{~W} \mathrm{~m}^{2} \mathrm{GR}\right.$ and $65 \%$ PGR), and soil moisture (31.4\% VSW) levels. However, when crown cover was lower than $40 \%$, the regeneration dynamics and growth performance was lower again. Beside this, higher canopy variables (CC and LAI) not only reduced both radiation transmittance (GR and PGR) and soil moisture content (VSW) but also increased seed production (Martínez Pastur et al. 2008) and consequently the density of the regeneration.

As we hypothesized, our height model for $N$. pumilio saplings showed a clear relationship with the extent of crown cover. The most favorable conditions (CC, LAI, GR, and PGR) were found in harvested forests, for example in shelterwood cuts $\left(30 \mathrm{~m}^{2} \mathrm{ha}^{-1} \mathrm{BA}\right)$, in edges of aggregated retention and close to the aggregates in dispersed retention $\left(15 \mathrm{~m}^{2} \mathrm{ha}^{-1} \mathrm{BA}\right)$ of variable retention cuts. Shelterwood cuts
Fig. 1 Model prediction of average seedling height after harvesting according to their age (A2 to A10 years) and crown cover (CC) (\%), effective leaf area index (LAI), global radiation (GR) $\left(\mathrm{W} \mathrm{m}^{2}\right)$ and percentage of global radiation (PGR) $(\%)$ at understory level transmitted through the canopy in Nothofagus pumilio forests

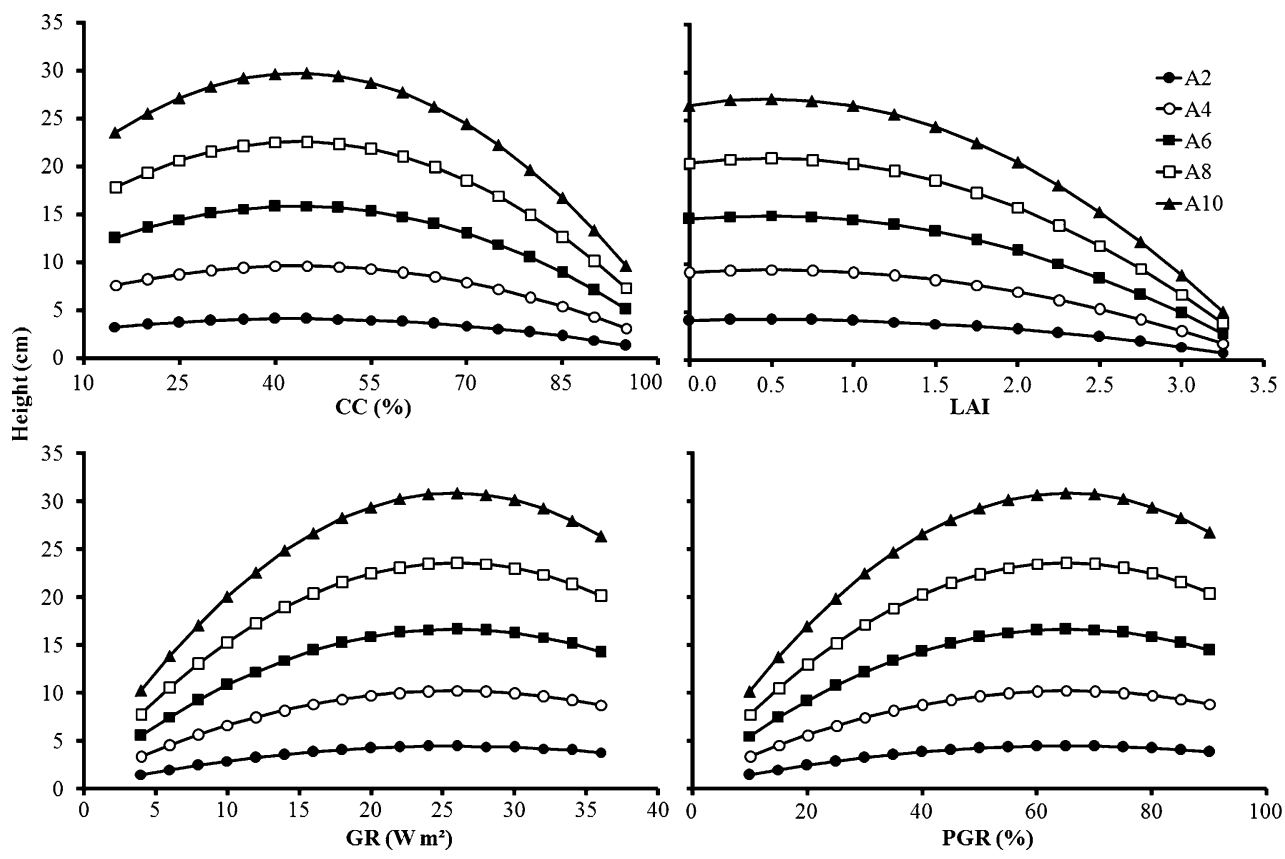




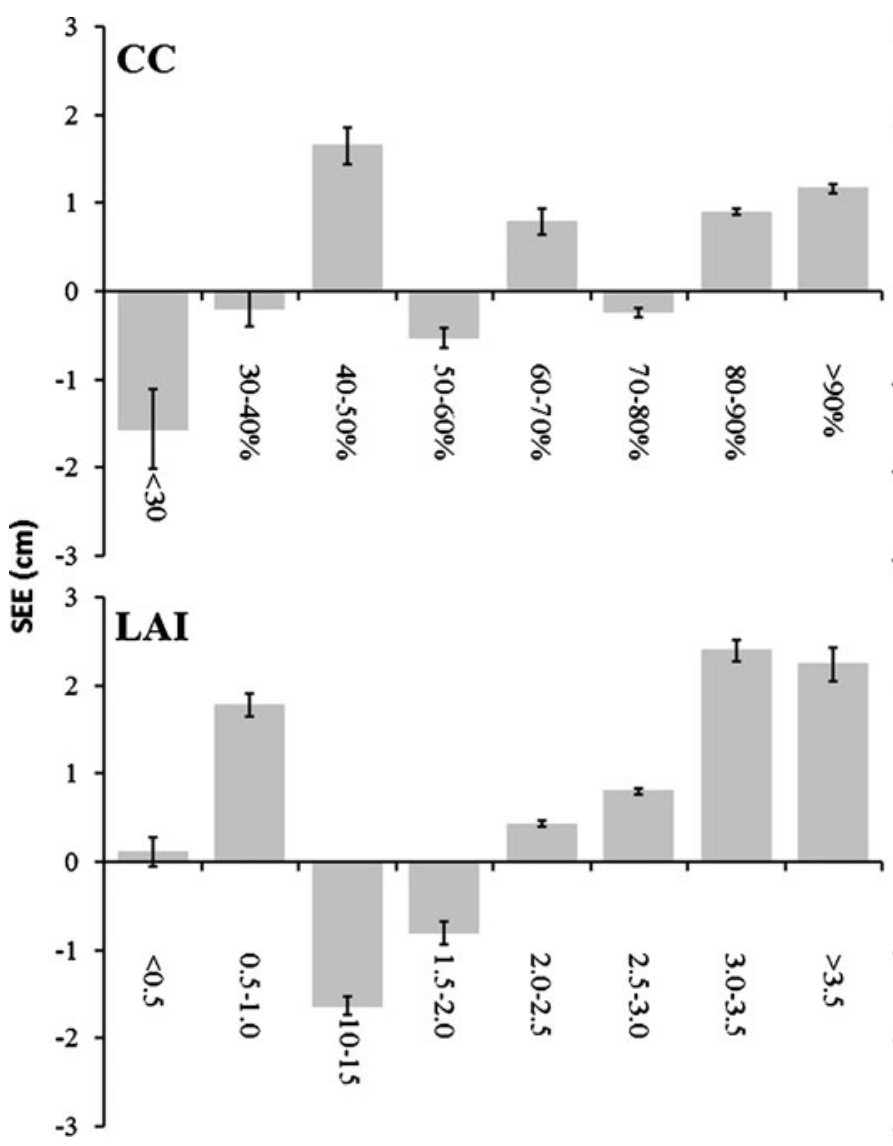

Fig. 2 Residual analysis (SEE - standard error of estimation) for the model prediction of average seedling height after harvesting analyzing crown cover (CC) (\%), effective leaf area index (LAI), global

homogenized the stand canopy structure, while variable retention cuts (dispersed and aggregated retention) produced a wide range of canopy covers (Martínez Pastur et al. 2009). Shelterwood cuts have been designed to maximize the regeneration height growth, while variable retention maintains a great diversity of microenvironments for biodiversity conservation purposes (Martínez Pastur et al. 2007a; Lencinas et al. 2008).

In pure $N$. pumilio forest in southern Patagonia, seedlings are the main woody component of the understory, constituting and responding as pioneer species after large-scale disturbances, and this tree is also the climax species of the final succession. For this reason, many authors classified it as a shade intolerant species (Richter and Frangi 1992; Veblen et al. 1997). However, when we analyzed its height growth, we determined that the species can be considered as mid-tolerant, as also determined by Martínez Pastur et al. (2007a) with regard to its photosynthesis efficiency, and Gutiérrez (1994) who suggest that Tierra del Fuego Nothofagus species are midtolerant due to their colonization abilities and their capability to survive under a higher crown cover of the overstory.
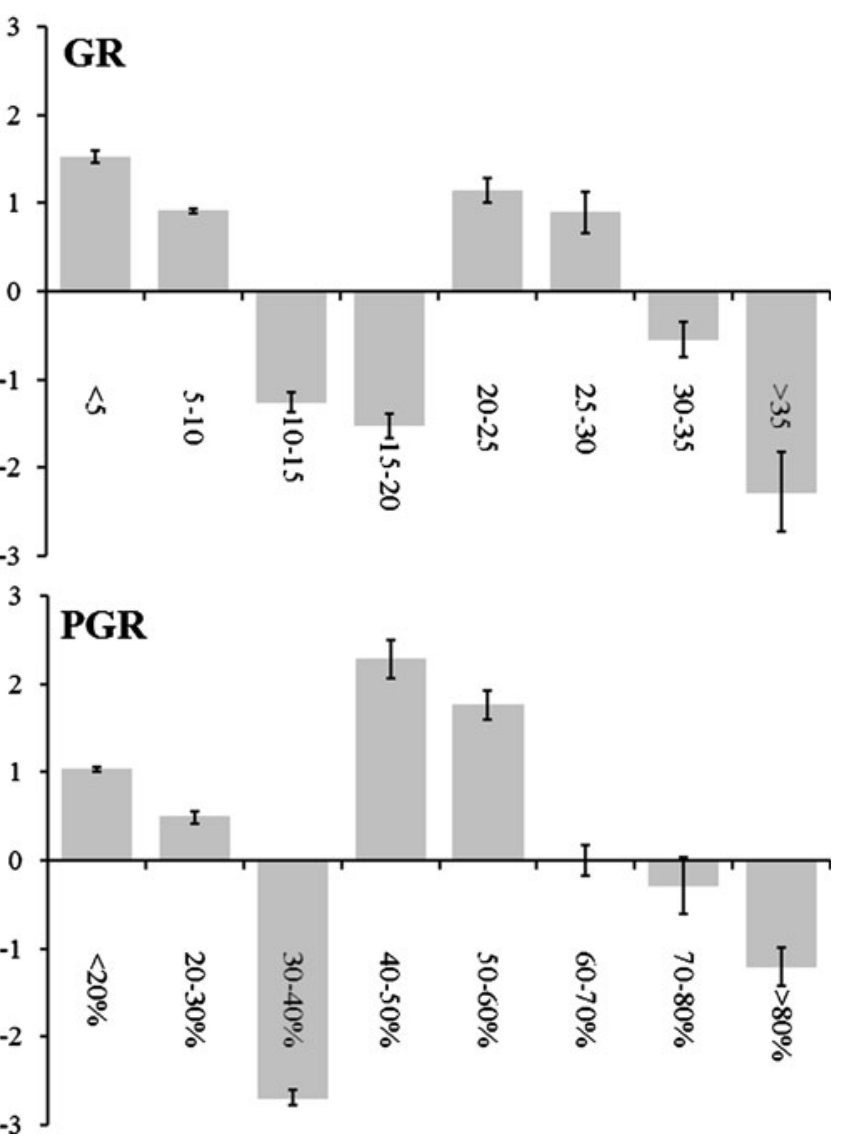

radiation $(\mathrm{GR})\left(\mathrm{W} \mathrm{\textrm {m } ^ { 2 }}\right)$ and percentage of global radiation (PGR) (\%) at understory level transmitted through the canopy in Nothofagus pumilio forests. Bars showed standard error of the mean

Mortality occurred mainly in younger and smaller seedlings due to natural self-thinning, browsing, or drought. For example, the scarce rainfall observed during November 2002-2003 just as bud sprout and seed germination occurred $(20-27 \mathrm{~mm}$ in November compared to 70-71 and 57-84 $\mathrm{mm}$ for October and December, respectively) induced greater mortality due to drought (Martínez Pastur et al. 2007b). Although we did not explicitly record browsing damage in this study, high losses by Lama guanicoe have been reported in previous studies both in primary forest and harvested stands (Pulido et al. 2000). While complete plants are removed by browsing when seedlings are small or young (less than 3-5 years), bigger or older plants are affected by bud grazing or by reduced height growth. Despite this, the regeneration density was sufficient to regenerate the stand (up to $40,000 \mathrm{ha}^{-1}$ saplings) (Martínez Pastur et al. 2007a). Seedling dynamics (recruitment, growth, and mortality) inside the aggregates were comparable to those found in old-growth forests, maintaining the original micro-environments of the primary forests. According to this study, regeneration systems for $N$. pumilio should include gradual canopy opening reaching up to $45 \%$ CC 
and 0.5 LAI for maximum potential height growth. The regeneration systems that maintain some degrees of retention such as group selection cuts (Bava and López Bernal 2005) should incorporate these retention ranges to maximize height growth at landscape level. Future silviculture practices should take into account the effect of light and soil moisture changes to maximize the potential growth in the natural regeneration, and consider the edge effects of retentions. These findings could also be used to estimate the potential for regeneration growth at larger scales using remote sensing data (e.g., aerial photograph interpretation) instead of the canopy variables measured directly here.

\section{Conclusions}

The natural regeneration dynamics of $N$. pumilio was closely related to the overstory canopy structure, which influenced seed production rates and the successful establishment, mortality and subsequent seedling growth. The canopy influence was determined by equilibrium between radiation transmittance levels and soil moisture availability favor seedling establishment and growth at crown cover levels of $40-60 \%$. Silvicultural systems that maintain crown cover at such levels are recommended for use in these forests.

Acknowledgments The authors gratefully thank the Centro Austral de Investigaciones Científicas, Ricardo Vukasovic of Servicios Forestales Consultancy, Los Cerros Ranch, San Justo Ranch, Kareken sawmill, and Los Castores sawmill for their support during this work. We also thank Sergio Luppo and María Elena Barlafina for provision of the radiation data and Mark Neyland of Forestry Tasmania for his comments about the manuscript.

\section{References}

Anderson C, Martínez Pastur G, Lencinas MV, Wallem P, Moorman MC (2009) Do introduced North American beavers engineer differently in southern South America? An overview with implications for restoration. Mammal Rev 39(1):33-52

Bava J, López Bernal PM (2005) Cortas de selección en grupo en bosques de lenga. IDIA-XXI 5(8):39-42

Caldentey J, Mayer H, Ibarra M, Promis A (2009) The effects of a regeneration felling on photosynthetic photon flux density and regeneration growth in a Nothofagus pumilio forest. Eur J Forest Res 128:75-84

Cuevas J (2002) Episodic regeneration at the Nothofagus pumilio alpine timberline in Tierra del Fuego, Chile. Ecology 90:52-60

Frangi JL, Richter L (1994) Balances hídricos de bosques de Nothofagus de Tierra del Fuego, Argentina. Rev Fac Agron La Plata 70:65-79

Frazer GW, Fournier RA, Trofymow JA, Gall RJ (2001) A comparison of digital and film fisheye photography for analysis of forest canopy structure and gap light transmission. Agric For Meteorol 109:249-263
Gea G, Martínez Pastur G, Cellini JM, Lencinas MV (2004) Forty years of silvicultural management in southern Nothofagus pumilio (Poepp. et Endl.) Krasser primary forests. For Ecol Manage 201(2-3):335-347

Gutiérrez E (1994) Els boscos de Nothofagus de la Terra del Foc com a paradigma de dinámica successional del no-equilibri. Treballs de la SCB 45:93-121

Hardya J, Melloha R, Koeniga G, Marksb D, Winstralb A, Pomeroyc J, Linkd T (2004) Solar radiation transmission through conifer canopies. Agric For Meteorol 126:257-270

Heinemann K, Kitzberger Th, Veblen Th (2000) Influences of gap microheterogeneity on the regeneration of Nothofagus pumilio in a xeric old-growth forest of northwestern Patagonia, Argentina. Can J For Res 30(1):25-31

Howard TM (1973) Studies in the ecology of Nothofagus cunninghamii Oerst. in natural regeneration on the Mt. Donna Buang Massif, Victoria. Aust J Bot 21(1):67-78

Lencinas MV, Martínez Pastur G, Moretto A, Gallo E, Busso C (2007) Productividad diferencial de plántulas de Nothofagus pumilio bajo gradientes de luz y humedad del suelo. Bosque 28(3):241248

Lencinas MV, Martínez Pastur G, Rivero P, Busso C (2008) Conservation value of timber quality vs. associated non-timber quality stands for understory diversity in Nothofagus forests. Biodiv Conserv 17:2579-2597

Martínez Pastur G, Peri P, Vukasovic R, Vaccaro S, Piriz CV (1997) Site index equation for Nothofagus pumilio Patagonian forest. Phyton 6(1/2):55-60

Martínez Pastur G, Cellini JM, Peri P, Vukasovic R, Fernández C (2000) Timber production of Nothofagus pumilio forests by a shelterwood system in Tierra del Fuego (Argentina). For Ecol Manage 134(1-3):153-162

Martínez Pastur G, Lencinas MV, Peri P, Arena M (2007a) Photosynthetic plasticity of Nothofagus pumilio seedlings to light intensity and soil moisture. For Ecol Manage 243(2):274282

Martínez Pastur G, Lencinas MV, Peri P, Moretto A, Cellini JM, Mormeneo I, Vukasovic R (2007b) Harvesting adaptation to biodiversity conservation in sawmill industry: Technology innovation and monitoring program. J Technol Manage Innov 2 (3):58-70

Martínez Pastur G, Lencinas MV, Peri P, Cellini JM (2008) Flowering and seeding patterns in unmanaged and managed Nothofagus pumilio forests with a silvicultural variable retention system. Forstarchiv 79:60-65

Martínez Pastur G, Cellini JM, Peri P, Lencinas MV, Gallo E, Soler ER (2009) Alternative silviculture with variable retention in timber management of South Patagonia. For Ecol Manage 258:436-443

Messier C, Doucet R, Ruel J, Claveau Y, Kelly C, Lechowicz J (1999) Functional ecology of advance regeneration in relation to light in boreal forests. Can J For Res 29:812-823

Mittermeier R, Mittermeier C, Robles-Gil P, Pilgrim J, Fonseca G, Brooks J, Konstant J (2002) Wilderness: Earth's last wild places. Cemex and Conservation International, Washington, $\mathrm{p} 573$

Nuñez M, Bowman D (1986) Nocturnal cooling in a high altitude stand of E. delegatensis as related to stand density. Aust For Res 16:185-197

Peri P, Martínez Pastur G, Lencinas MV (2009) Photosynthetic and stomatal conductance responses to different light intensities and water status of two main Nothofagus species of south Patagonian forest. For Sci 55(3):101-111

Pulido F, Díaz B, Martínez Pastur G (2000) Incidencia del ramoneo del guanaco (Lama guanicoe) sobre la regeneración de lenga (Nothofagus pumilio) en bosques de Tierra del Fuego, Argentina. Invest Agr: Sist Rec For 9(2):381-394 
Rebertus A, Veblen Th (1993) Structure and tree-fall gap dynamics of old-growth Nothofagus forests in Tierra del Fuego, Argentina. J Veg Sci 4(5):641-654

Rebertus A, Kitzberger T, Veblen Th, Roovers L (1997) Blowdown history and landscape patterns in the Andes of Tierra del Fuego, Argentina. Ecology 78(3):678-692

Richter L, Frangi J (1992) Bases ecológicas para el manejo del bosque de Nothofagus pumilio de Tierra del Fuego. Rev Fac Agron La Plata 68:35-52

Roxburgh JR, Kelly D (1995) Uses and limitations of hemispherical photography for estimating forest light environments. NZ J Ecol 19(2):213-217

Santana A (2006) Resumen meteorológico año 2005 Estación “Jorge C. Schythe" (5308'S; $70^{\circ} 53^{\prime} \mathrm{W} ; 6$ m.s.n.m.). Ann Inst Patagonia 34:81-90
Santana A, Porter Ch, Butorovic N, Olave C (2006) Primeros antecedentes climatológicos de estaciones automáticas (AWS) en el Canal Beagle, Magallanes, Chile. Ann Inst Patagonia 34:520

Stenburg P, Linder S, Smolander H, Flower-Ellis J (1994) Performance of the LAI-2000 plant canopy analyzer in estimating leaf area index of some Scots pine stands. Tree Physiol 14:981-995

Sun OJ, Sweet GB, Whitehead D, Buchan GD (1995) Physiological responses to water stress and waterlogging in Nothofagus species. Tree Physiol 15:629-638

Veblen Th, Kitzberger T, Burns B, Rebertus A (1997) Perturbaciones y dinámica de regeneración en bosques andinos del sur de Chile y Argentina. In: Armesto J, Villagrán J, Arroyo MK (eds) Ecología de los bosques nativos de Chile. Editorial Universitaria, Santiago, Chile, pp 169-198 